Reprod. Nutr. Dévelop., 1988, 28 (4 A), 939-952

\title{
Biochemical analysis of vitellogenin from rainbow trout (Salmo gairdneri): fatty acid composition of phospholipids
}

\author{
Lucie FREMONT, A. RIAZI
}

Station de Recherches de Nutrition, I.N.R.A., 78350 Jouy-en-Josas, France.

Summary. Vitellogenin was obtained from three year-old vitellogenic trout.

Two procedures of isolation were compared: dialysis against distilled water and ultracentrifugation in the density interval $1.21-1.28 \mathrm{~g} / \mathrm{ml}$.

Similar patterns were observed by gel filtration and electrophoresis for both preparations of vitellogenin, indicating that electric charge and molecular weight were not modified by either procedure.

The apparent $M_{r}$ of the native form was 560,000 in gel filtration, whereas that of the monomer was estimated as 170,000 by sodium dodecylsulfate-polyacrylamide gel electrophoresis. Minor proteins were also detected $(100,000-88,000-78,000)$.

The main components were protein $(79 \%)$, and lipids $(19 \%)$. Carbohydrates accounted for $0.3 \%$ when protein phosphorus and calcium each represented $0.7 \%$ of total weight.

Phospholipids ( $70 \%$ of total lipids) mainly consisted of phosphatidylcholine in which n-3 docosahexanenoic acid accounted for one-third of total fatty acids.

The results show the high levels of essential fatty acids in structural lipids which are known to be involved in embryo development.

\section{Introduction.}

Vitellogenin (VTG), the lipophosphoprotein synthesized during vitellogenesis by oviparous vertebrates, has been characterized in some fish species including rainbow trout (Hara and Hirai, 1978; Campbell and Idler, 1980; Norberg and Haux, 1985). The complex is generally isolated by precipitation. However VTG can be obtained by ultracentrifugation keeping the complex in a soluble form.

Previously (Fremont et al., 1984) we used sequential ultracentrifugation for comparing chemical composition and fatty acid distribution in VTG and plasma lipoproteins $(\mathrm{d}<1.21 \mathrm{~g} / \mathrm{ml})$ obtained by the same procedure. However, it is quite possible that methods used for isolation change the properties of VTG, specially that related to the insolubility of the complex in aqueous solutions. In the present study we therefore compared some properties of VTG obtained either by ultracentrifugation $\left(V T G_{U}\right)$ or by dialysis against bidistilled water $\left(V T G_{D}\right)$. 
In addition, we characterized the phospholipid moiety of VTG which is the main vehicle for the essential fatty acids involved in the embryonic development of trout (Leray et al., 1985).

\section{Material and methods.}

\section{Animals.}

Three year-old female trout (Salmo gairdneri) from an autumn strain were reared at $9-15^{\circ} \mathrm{C}$ in a fish farm under the control of the «Institut National de la Recherche Agronomique, France ». Fish were fed a commercial diet in which protein and lipid accounted for $43-45 \%$ and $8-10 \%$, respectively, of the dry matter. The essential n-3 polyunsaturated fatty acids (PUFA) were provided at a level of $1 \%$ of the diet (in weight). When serum VTG reached a high level (September-October), blood was taken after one-week starvation by puncture in the dorsal caudal artery. Serum was isolated by a low-speed centrifugation and antiproteolytic agents were added : $0.01 \%$ sodium azide $\left(\mathrm{NaN}_{3}\right)$ and $0.005 \%$ phenylmethylsulfonylfluoride (PMSF). Samples were stored at $-80^{\circ} \mathrm{C}$ until analysis.

\section{Analytical procedures.}

\section{- Isolation of vitellogenin.}

Dialysis. - A volume of serum was introduced into a membrane tubing (Spectrapor) and placed for dialysis in bidistilled water (5/ for $30 \mathrm{ml}$ serum) at $4{ }^{\circ} \mathrm{C}$ for 2 days. After $3-4$ changes of water, the precipitated VTG was collected by a 30 -min centrifugation at $15000 \times \mathrm{g}$ and solubilized in $0.5 \mathrm{M} \mathrm{NaCl}$. It was twice purified by reprecipitation in 10 vol. of distilled water. The final material was designed as $\mathrm{VTG}_{\mathrm{D}}$.

U/tracentrifugation. - Serum lipoproteins of $\mathrm{d}<1.21 \mathrm{~g} / \mathrm{ml}$ were isolated by flotation in a $\mathrm{NaCl}-\mathrm{KBr}$ solution according to Havel, Eder and Bragdon (1955) for $40 \mathrm{~h}$ at $10^{\circ} \mathrm{C}$. A rotor $50 \mathrm{Ti}$ Beckman was operated at $145000 \times \mathrm{g}$. After removing lipoproteins, the subnatant fraction was raised to $\mathrm{d}=1.28 \mathrm{~g} / \mathrm{ml}$. The floating VTG was obtained after a $72-\mathrm{h}$ run at $10^{\circ} \mathrm{C}$ and collected as previously described (Fremont et al., 1984).

The VTG containing saline solution was exhaustively dialyzed against $0.5 \mathrm{M} \mathrm{NaCl}$ to remove $\mathrm{KBr}$ and the excess of $\mathrm{NaCl}$. The final material was designed as $\mathrm{VTG}_{\mathrm{U}}$.

Gel filtration. - Several trade marks of beads were used : Sepharose CL 6B, Sephacryl S 300 (Pharmacia fine Chemical, Upsala, Sweden), AcA 22 (IBF, France) and Biogel 1.5 M (Biorad, Richmond, USA). The elution solvent was $0.5 \mathrm{M} \mathrm{NaCl}$ containing $0.01 \% \mathrm{NaN}_{3}$ and $0.005 \%$ PMSF. In some assays, the influence of ionic strength $(\mu)$ and $\mathrm{Ca}^{2+}$ were tested. The saline solutions were : 
$0.5 \mathrm{M} \mathrm{NaCl}(\mu=0.5) ; 0.8 \mathrm{M} \mathrm{NaCl}, 0.5 \mathrm{M} \mathrm{NaCl}+0.1 \mathrm{M} \mathrm{MgCl}_{2}, 0.5 \mathrm{M} \mathrm{NaCl}+$ $0.1 \mathrm{M} \mathrm{CaCl}_{2}(\mu=0.8) ; 1.25 \mathrm{NaCl}(\mu=1.25) ; 0.5 \mathrm{M} \mathrm{MgCl}, 0.5 \mathrm{M} \mathrm{CaCl}_{2}$ $(\mu=1.5)$. Before each fractionation, the column was equilibrated with the elution solvent for at least 2 days. The sample of VTG (20-50 mg protein) was applied to the column $(1.5 \times 90 \mathrm{~cm}$ or $1.6 \times 100 \mathrm{~cm})$ and eluted with the tested buffer at a flow rate of 10 (or 12) $\mathrm{ml} \mathrm{h}^{-1}$; fractions of $2.5 \mathrm{ml}$ were collected after monitoring absorbance at $280 \mathrm{~nm}$. The column was calibrated for molecular weights $\left(M_{r}\right)$ with standard proteins : thyroglobulin $(669,000)$, ferritin $(440,000)$, and catalase $(232,000)$. The markers Escherichia coli and tryptophane were used to determine the void volume $\left(V_{0}\right)$ and the total volume $\left(V_{t}\right)$ respectively. The apparent $M_{r}$ of VTG which was eluted at $V_{e}$ was estimated from the linear relation $K_{A V}=f \log M_{r}$ with $K_{A V}=V_{e}-V_{0} / V_{t}-V_{0}$.

Electrophoretic methods. - Agarose gel electrophoresis was carried out according to Noble (1968) as previously described (Fremont et al., 1981). Proteins were visualized by Amidoblack $10 \mathrm{~B}$.

Polyacrylamide gel electrophoresis (PAGE) in non-denaturing conditions was performed by the method of Davis (1964) on $5 \%$ gels using the vertical slab apparatus of Biorad (Protean 32 cell). The molecular weights of subunits were estimated by SDS-PAGE in linear gradient of 3-15\% polyacrylamide according to Laemmli (1970) using the following markers: myosine $(200,000)$, galactosidase $(116,250)$, phosphorylase b $(92,500)$, bovine serum albumin $(66,200)$, ovalbumin $(45,000)$. In some assays, samples were incubated at $100^{\circ} \mathrm{C}$ for $3 \mathrm{~min}$ in the presence of a reducing agent (one-fifth of the volume of $400 \mathrm{mM}$ dithiothreitol).

The sample of protein (ca $50 \mu \mathrm{g}$ per well) was deposited in glycerol. Bromophenol blue was used as a tracing dye. The running time was $4-5 \mathrm{~h}$ at $50 \mathrm{~mA}$ per slab in electrode buffer TRIS-glycine, $\mathrm{pH}$ 8.3. Afterwards, migration gels were stained for proteins with Coomassie Brillant blue R 250 .

\section{- Chemical analysis.}

Lipids were extracted with chloroform-methanol (2:1) according to Folch et al. (1957) Triglycerides and cholesterol were quantified using enzymatic procedures (Biochemica test combination, Boehringer, Mannheim, France). Lipid phosphorus was estimated by a modification of the method of Bartlett (1959). All reactions were performed in the same tube using a heating block to mineralize the lipid extract with $10 \mathrm{NH}_{2} \mathrm{SO}_{4}$. The color was developed at $100^{\circ}$ after adding the Fiske and Subbarow reagent and the optical density read at $830 \mathrm{~nm}$.

The phosphorus content was estimated from a standard curve obtained with $\mathrm{HKPO}_{4}$ and phospholipids calculated by multiplying the phosphorus value by 25 considering lecithin as the major phospholipid. Phosphoproteins were assayed as acid-insoluble-nonlipid phosphorus according to Bergink et al. (1973). After washing the precipitate by solvents, protein phosphorus was estimated in the same way as lipid phosphorus. 
For qualitative identification, lipid classes were separated by thin-layer chromatography on Silicagel $H$ (Merck). The developing solvent system was hexane - diethyl ether — formic acid $(80-20-2 \mathrm{v} / \mathrm{v} / \mathrm{v})$ for total lipids and nonpolar lipids; the solvent system was methanol/hexane/acetic acid/boric acid (40-20-30-10-1.8 v/v/v/v/w) for phospholipids (Gilfillan et al., 1983).

For quantitative analysis, a silica cartridge $(25 \mathrm{~mm} \times 10 \mathrm{~mm}$ ) (SEP-Pack waters, Framingham, USA) was used to separate non-phosphorus lipids from phospholipids with $30 \mathrm{ml}$ of chloroform followed by $5 \mathrm{ml}$ of chloroform/methanol (Juaneda and Rocquelin, 1985). Phospholipid molecular classes were separated by high-performance liquid chromatography (HPLC) using a Beckman apparatus. The column $(10 \times 250 \mathrm{~mm})$ was packed with silica $(5 \mu \mathrm{m}$ ultrasphere-Si) ; the chromatographic system was programmed for elution using two solvent systems (Geurts Van Kessel et al., 1977). System A : hexane/2 propanol/water (6-8-0.75 by vol.) and system $B$ : hexane/2 propanol/water (6-8-1.4 by vol.).

A linear gradient elution ranging from 0 to $100 \%$ of solvent $B$ was used for $10 \mathrm{~min}$. The phospholipid extract $(3-5 \mathrm{mg}$ ) was applied to the column in $500 \mu \mathrm{l}$ of hexane/ 2 propanol ( $6-8$ by vol.). Peaks were detected at $206 \mathrm{~nm}$ and fractions containing the separated phospholipids were collected for phosphorus estimation and fatty acid composition.

The methyl esters of fatty acids were obtained by transmethylation with $10 \% \mathrm{HCl}$ in methanol. The analysis was performed by gas-liquid chromatography (GLC) in a Packard chromatograph (model 427) fitted with a flame ionization detector. A $50 \mathrm{~m} \times 0.2 \mathrm{~mm}$ vitreous silica capillary column with $\mathrm{CP}$ wax $52 \mathrm{CB}$ (Chrompack, France) phase was used. The column was programmed from $140^{\circ} \mathrm{C}$ to $225^{\circ} \mathrm{C}$ at $6{ }^{\circ} \mathrm{C} / \mathrm{min}$. The injector and detector temperatures were $250{ }^{\circ} \mathrm{C}$ and $290^{\circ} \mathrm{C}$, respectively. The carrier gas was hydrogen at a flow rate of $2 \mathrm{ml} / \mathrm{min}$. The peaks were identified with standards by calculating the equivalent chain length using a Delsi (Enica 10) integrator equipped with a microcomputer proceeding to an automatic expression of percentages.

Protein was estimated by the technique of Lowry et al. (1951) using bovine serum albumin as the standard.

Amino acids were determined after acid hydrolysis in $6 \mathrm{~N} \mathrm{HCl}$ with norleucine as the internal standard for $24 \mathrm{~h}$ and $48 \mathrm{~h}$ at $115^{\circ} \mathrm{C}$ in sealed test tubes. Hydrolysates were analyzed using a Liquimat III, Kontron analyzer equipped with a polystyrene sulfonic (DC-6A $10 \mu \mathrm{m})$ resin column $(0.4 \times 30 \mathrm{~cm})$. A computing integrator was used for calculations.

Hexoses were estimated according to Winzler (1955) using the $\mathrm{H}_{2} \mathrm{SO}_{4}$ orcinol reaction. Hexosamines were obtained by the method of Rondle and Morgan (1955) modified by Kraan and Muir (1957) based on the reaction of Ehrlich, D-galactosamine and D-glucosamine were used as standards. Sialic acids were analyzed according to Svennerholm (1957) using $\mathrm{N}$-acetyl neuraminic acid.

Calcium was determined by flame-emission-spectrophotometry (Eppendorf apparatus). In some assays VTG was mineralized at $550^{\circ}$ for $12 \mathrm{~h}$ before quantification of the cation. 


\section{Results and discussion.}

Molecular filtration of $V_{T G}$ or $V T G_{D}$ on Sepharose $C L 6 B$ Biogel $1.5 \mathrm{M}$, Sephacryl S 300 or AcA 22 gave a single peak when a saline solution of $\mathrm{NaCl}$ was used as eluant (fig. 1), whatever the ionic strength ( $\mu=0.5,0.8,1.25$ or 1.5). When $\mathrm{NaCl}$ was partially or totally replaced by a $\mathrm{Ca}^{2+}$-containing saline solution, the same profile was obtained with either gel except with AcA 22. On this gel, VTG eluted as a broad fraction showing a shoulder on the ascending slope. This fraction was incompletely resolved into two closely spaced peaks; they eluted in the region of the unique peak obtained in the absence of $\mathrm{Ca}^{2+}$ but the apparent $\mathrm{M}_{\mathrm{r}}$ could not be estimated because of band spreading. When $\mathrm{Mg}^{2+}$ replaced $\mathrm{Ca}^{2+}$ without changing the ionic strength, no effect was observed. Only $\mathrm{Ca}^{2+}$ changed the profile, whatever the ionic strength, and there was no relation between the elution profile and the concentration of the cation in the buffer. This observation was unexpected considering that $\mathrm{Ca}^{2+}$ is a normal component of VTG. In the native complex the cation is not masked since similar values were obtained when $\mathrm{Ca}^{2+}$ was estimated either in crude VTG or after mineralization of the complex. The calcium binding properties of VTG is well described in amphibians. One atom of calcium would be associated with every protein phosphate group (Wallace, 1970) but any associated calcium can be removed by gel filtration (Ansari et al., 1971; Wallace and Bergink, 1974). The binding of $\mathrm{Ca}^{2+}$ with the phosphate moiety of VTG was also described in other oviparous vertebrates, fish (Hori, Kodama and Tanahashi, 1979) and birds (Verrinder Gibbins and Robinson, 1982).

According to Wiley, Opresko and Wallace (1979), the complex remained soluble in serum because of the presence of other proteins but the addition of divalent cations to purified VTG resulted in VTG precipitation without degradation except when $\mathrm{Ca}^{2+}$ was used. The authors suggest that the extensive degradation of VTG might be caused by a $\mathrm{Ca}^{2+}$-activated protease. Such a degradative effect of $\mathrm{Ca}^{2+}$ on our purified VTG might explain the heterogeneous shape of the peak eluted from AcA 22 while the unaltered profile obtained on other gels could be due to a lower capacity of resolution.

Another explanation might be the existence of changes in the hydrophobicity of VTG induced by the added $\mathrm{Ca}^{2+}$. The zone spreading observed on AcA 22 would be related to the ability of this gel to interact with the modified VTG.

The apparent $M_{r}$ estimated on the gels from the elution volume in the absence of $\mathrm{Ca}^{2+}$ was 560,000 ; the value was between that found by Hara and Hirai (1978) and Campbell and Idler (1980) (600,000 and 440,000 respectively).

Both peaks obtained from $V_{T G}$ or $V_{T} G_{D}$ after gel filtration migrated close to the origin at $\mathrm{pH} 8.6$ as a prominent band in agarose electrophoresis (fig. 2). When either VTG was subjected to polyacrylamide gel electrophoresis under nondissociating conditions a single slow migrating band was also observed.

The SDS electrophoretic patterns of purified VTG were also similar for VTG and $V T G_{D}$ showing several bands after protein staining. The $M_{r}$ of the main band was 170,000 while those of minor bands were $110,000,88,000,78,000$. The main band represented most likely the VTG monomer corresponding to the 


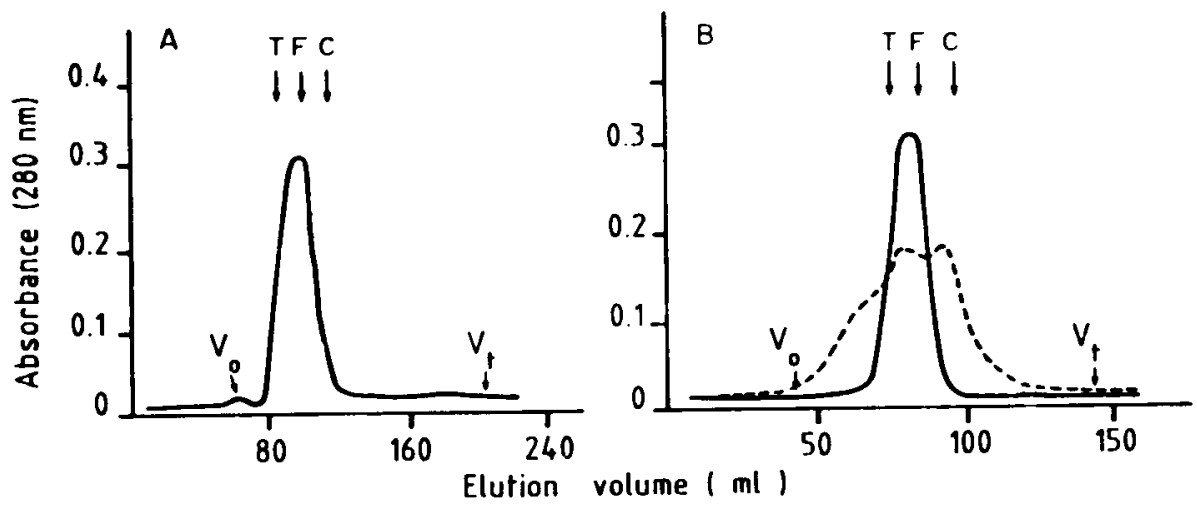

FIG. 1. - Gel fittration of trout vitellogenin obtained either by ultracentrifugation, or by dialysis ; serum was obtained from female trout during vitellogenesis. $20-50 \mathrm{mg}$ of protein was applied to the column in the appropriate saline solution.

A. Sephacryl S-300 was packed in a $1.6 \times 100 \mathrm{~cm}$ column. The protein was eluted with a saline solution at the flow rate of $12 \mathrm{ml} \mathrm{h}^{-1}$. The same profile was obtained whatever the elution solvent $0.5 \mathrm{M} \mathrm{NaCl} ; 0.8 \mathrm{M} \mathrm{NaCl} ; 0.5 \mathrm{M} \mathrm{NaCl}+0.1 \mathrm{M} \mathrm{MgCl}_{2} ; 0.5 \mathrm{M} \mathrm{NaCl}+0.1 \mathrm{M} \mathrm{CaCl}_{2}$.

B. AcA 22 was packed in a $1.5 \times 90 \mathrm{~cm}$ column. The protein was eluted with a saline solution at the flow rate of $10 \mathrm{ml} \mathrm{h}{ }^{1}$.

The profile $(\stackrel{\longrightarrow}{\longrightarrow}$ was obtained with the following elution solvents : $0.5 \mathrm{M} \mathrm{NaCl} ; 0.8 \mathrm{M}$ $\mathrm{NaCl} ; 0.5 \mathrm{M} \mathrm{NaCl}+0.1 \mathrm{M} \mathrm{MgCl}_{2} ; 0.5 \mathrm{M} \mathrm{MgCl}_{2}$.

The profile (- - ) was obtained with $0.5 \mathrm{M} \mathrm{NaCl}+0.1 \mathrm{M} \mathrm{CaCl}_{2}$ or $0.5 \mathrm{M} \mathrm{CaCl}_{2}$ as elution solvent.

The apparent $\mathrm{M}_{\mathrm{r}}$ was determined in $0.5 \mathrm{M} \mathrm{NaCl}$. The standard proteins used as markers were : thyroglobulin $(T)$, ferritin (F) and catalase (C).

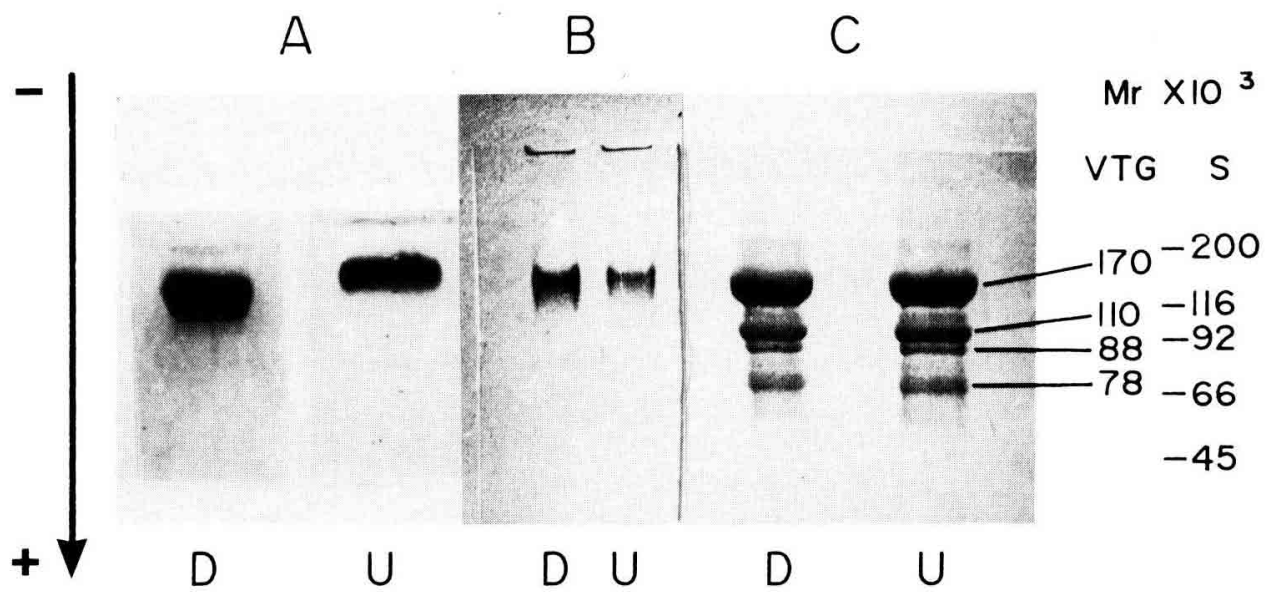

FIG. 2. - Gel electrophoresis of trout vitellogenin (VTG) obtained by uitracentrifugation (U) or by dialysis (D) and purified by gel filtration on AcA 22 using $0.5 \mathrm{M} \mathrm{NaCl}$ as eluting buffer.

A. $0.8 \%$ agarose plates at $\mathrm{pH}$ 8.6. Protein was stained by Amidoblack $10 \mathrm{~B}$. B. PAGE in $5 \%$ polyacrylamide slab under non dissociating conditions. Protein was stained by Coomassie Brillant blue R 250. C. SDS-PAGE in linear gradient of 3-15\% polyacrylamide in the presence of dithiothreitol. Molecular weights were estimated by standards (S) as described in Material and Methods. Protein was stained by Coomassie Brillant blue R 250 . 
protein described by others [Hara and Hirai (1978), $M_{r} 220,000$; Chen (1983), $M_{r} 170,000 ;$ Babin (1987), $\left.M_{r} 175,000\right]$.

The comparison of this pattern to that obtained in gel filtration indicated that the dissociation of peptides having lower molecular weights than the monomer only occurred when electrophoresis was performed in the presence of SDS. The similarity between $\mathrm{VTG}_{U}$ and $\mathrm{VTG}_{\mathrm{D}}$ in gel filtration and electrophoresis showed that the step of precipitation did not cause major structural modifications in the complex.

Chemical analysis of $\mathrm{VTG}_{U}$ (table 1) revealed the predominance of protein ( $79 \%$ by weight). Protein phosphorus accounted for $0.7 \%$ of total VTG or $0.88 \%$ reported to the protein moiety $(0.028$ atom per $100 \mathrm{~g})$.

\section{TABLE 1}

Chemical composition of trout vitellogenin obtained by ultracentrifugation in the density range of $1.21-1.28 \mathrm{~g} / \mathrm{ml}$.

\begin{tabular}{lcc}
\hline Component & Weight (\%) \\
\hline Protein & 79 & \\
Lipid & 19 & $70^{*}$ \\
phospholipid & 13,3 & 22 \\
triglyceride & 4,2 & 8 \\
cholesterol & 1,5 & $22^{* *}$ \\
Carbohydrate & 0,3 & 25 \\
sialic acid & & 53 \\
hexosamine & & \\
hexose & 0,7 & \\
Protein phosphorus & 0,7 & \\
Calcium & & \\
\hline
\end{tabular}

* \% of total lipids ; ${ }^{* *} \%$ of total carbohydrates.

The values estimated by Campbell and Idler (1980) and by Norberg and Haux (1985) were slightly lower : 0.6 and 0.63 per $100 \mathrm{~g}$ of protein, respectively. The percentages were similar in goldfish since Hori, Kodama and Tanahashi (1979) found $0.7 \%$ and De Vlaming et al. (1980) $0.79 \%$. As reported by the latter authors, the protein phosphorus content of VTG from several species of fish is low compared to that of VTG from Xenopus laevis (Wallace, 1970) and birds (Deeley et al., 1975 ; Verrinder Gibbins, Van de Voort and Braham, 1981). The complex contained $0.7 \%$ calcium; thus the calculated atomic phosphorus ratio was 0.77 assuming that calcium phosphatidyl residues were not all bound to calcium. VTG lipids (19\% of total weight) consisted of phospholipids (70\%), triglycerides $(22 \%)$ and cholesterol (8\%). The distribution was similar to that previously reported for VTG obtained by ultracentrifugation (Fremont et al., 1984) and to that found by Norberg and Haux (1985) for VTG isolated by selective precipitation using $\mathrm{Mg}^{2+}$. 
As reported by Hara and Hirai (1978), carbohydrates were present but they were minor components, comprising $0.3 \%$ of VTG; this content was lower than that of Xenopus VTG (Tata, 1976).

The amino acid distribution (table 2) resembled that reported by Campbell and Idler (1980), Hara and Hirai (1978) for trout. The major amino acids were alanine, glutamic acid and leucine. The molar ratio serine/protein phosphorus was $0.055 / 0.028$, showing that about half of seryl residues were phosphorylated in trout VTG (it was possible that some threonyl residues were also phosphorylated).

TABLE 2

Amino acid composition of trout vitellogenin. Values are expressed in per cent by weight and in residue per cent mol of total amino acids.

\begin{tabular}{lcc}
\hline Amino acid & $\mathrm{g}(\%) \pm$ SEM $^{*}$ & $\mathrm{~mol}(\%)$ \\
\hline Asp & $9,05 \pm 0,21$ & 8,6 \\
Thr & $5,00 \pm 0,17$ & 5,4 \\
Ser & $5,88 \pm 0,19$ & 7,1 \\
Pro & $6,30 \pm 0,81$ & 6,8 \\
Glu & $11,31 \pm 0,28$ & 9,8 \\
Gly & $2,24 \pm 0,15$ & 3,8 \\
Ala & $8,25 \pm 0,49$ & 11,7 \\
Cys/2 & $1,22 \pm 0,10$ & 1,7 \\
Val & $7,22 \pm 0,09$ & 7,8 \\
Met & $1,71 \pm 0,08$ & 1,5 \\
le & $6,10 \pm 0,47$ & 5,9 \\
Leu & $9,61 \pm 0,10$ & 9,3 \\
Tyr & $3,84 \pm 0,08$ & 2,7 \\
Phe & $4,93 \pm 0,09$ & 3,8 \\
Lys & $8,74 \pm 0,06$ & 7,6 \\
His & $2,54 \pm 0,09$ & 2,0 \\
Arg & $6,05 \pm 0,27$ & 4,4 \\
\hline
\end{tabular}

* Mean of three determinations after a $24 \mathrm{~h}(\times 1)$ or a $48 \mathrm{~h}(\times 2)$ hydrolysis.

When comparing the present results to those obtained by others, it appears that the distribution of the main components was similar, whatever the source of VTG : mature female trout (Hara and Hirai, 1978 ; this study) estrogenized male trout (Campbell and Idler, 1980), estrogenized juvenile trout (Norberg and Haux, $1985)$ or vitellogenic trout receiving an n-3 deficient or non-deficient diet (Fremont et al., 1984). Moreover, analyses performed during the last 5 months before ovulation did not show any change in the proportions of protein and lipid classes (Riazi and Fremont, 1988).

The present results support the hypothesis that VTG is secreted as a homogeneous complex having a definite distribution of molecular species during the course of vitellogenesis. 
However, the level of some components, namely PUFA, only provided by diet, decreased when trout were fed a n-3 PUFA deficient diet during vitellogenesis (Fremont et al., 1984). As phospholipids are the major PUFA vehicles in VTG, we determined fatty acid distribution in this class of structural lipids when diet supplied the required levels.

Figure 3 shows the profiles obtained by TLC and HPLC, revealing the predominance of phosphatidylcholine which accounted for $83 \%$ of the total phospholipids (table 3 ). The fatty acid distribution in phosphatidylcholine (PC)

TABLE 3

Distribution of phospholipid classes in trout vitellogenin.

Phospholipid class

Phosphatidylcholine (PC)

Lysophosphatidylcholine

(LPC)

Phosphatidylethanolamine

(PE)

Phosphatidylserine (PS)

Phosphatidylinositol (PI)

Sphingomyelin (SM)
$\%$ of total phospholipid phosphorus

Data are expressed as mean \pm SEM of two independant determinations. Each of them was performed on pooled samples of serum from four fish.

and phosphatidylethanolamine (PE) is reported in table 4. It is clear that in both classes, total saturated fatty acids represented less than one third of the total fatty acids. Monounsaturated fatty acids (the main one was oleic acid) were minor components when PUFA accounted for almost half of the total fatty acids $(47.6 \%$ in $P C$ and $44.4 \%$ in PE). The $n-3 / n-6$ ratio was 4.5 in $P C$ and only 2 in PE.

In a previous experiment (Fremont et al., 1984), the percentage of the docosahexaenoic acid $(22: 6 n-3)$ relative to total VTG fatty acids were in the same range in September $(23: 3)$ and December (25.4) when trout were fed an $\mathrm{n}-3$ containing diet. By contrast a $\mathrm{n}-3$ depleted diet had a lowering effect.

The present data show that $P C$ is the main vehicle of this essential fatty acid. The amount can be estimated from VTG composition and PC percentages in the lipid moiety. By this calculation, the PC $22: 6 n-3$ accounted for $3.9 \%$ of the VTG weight.

It is well known that fatty acid chains of phospholipids play a key role in the structure of lipoproteins of $\mathrm{d}<1.21 \mathrm{~g} / \mathrm{ml}$ (Segrest et al., 1974). VTG is a peculiar lipoprotein since it is characterized by a strong hydrophobicity; however, it can be expected that, in relation with the length and degree of unsaturation, the arrangement of phospholipids and proteins also depends on the spatial organization of the acid chains. Alterations in embryonic development observed when 


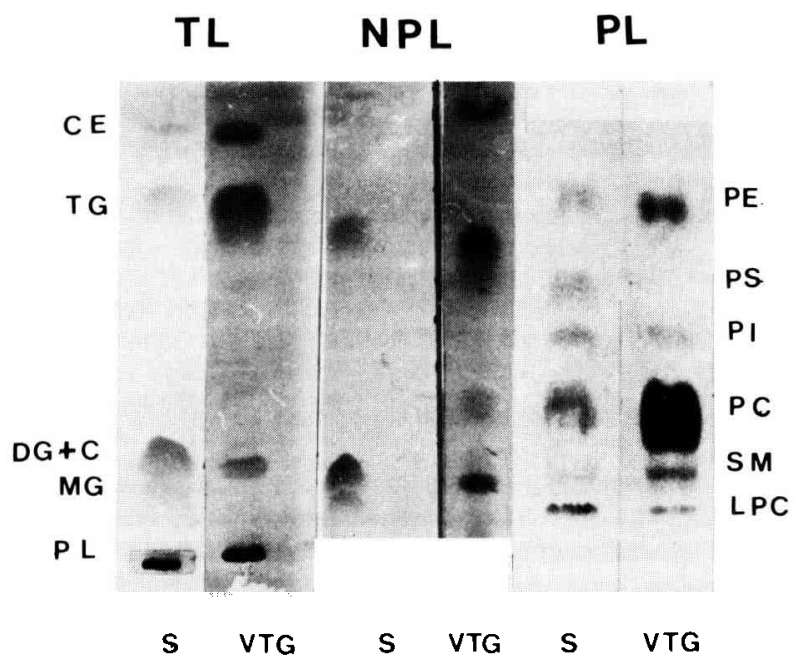

$S \quad$ VTG $\quad S \quad$ VTG $S \quad$ VTG

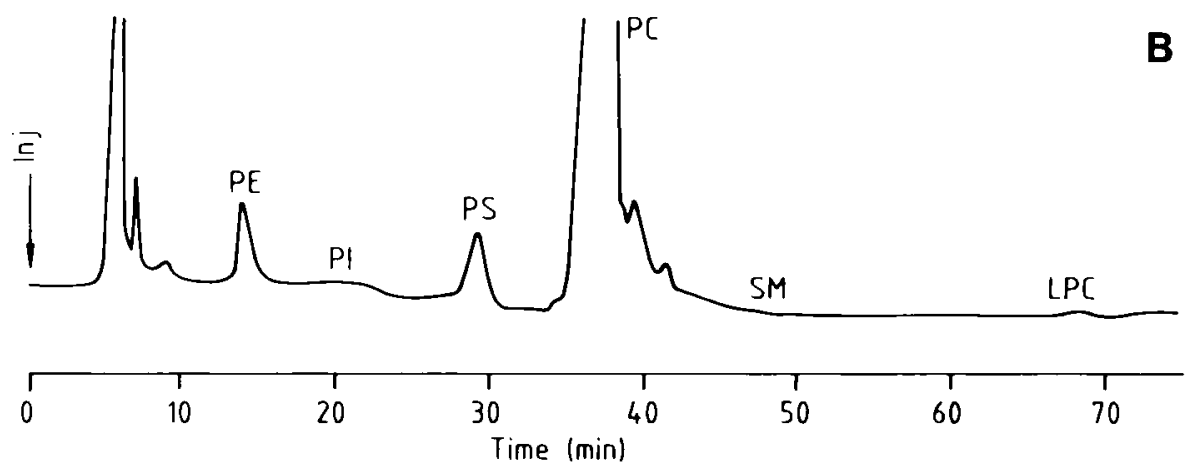

FIG. 3. - Fractionation of lipid classes in trout vitellogenin (VTG).

A. Thin-layer chromatography on $0.25-\mathrm{mm}$ thick silica gel $H$ plates. Total lipids (TL) and non-phosphorylated lipids (NPL) were eluted using hexane-, ethyl ether-, formic acid $(80 / 20 / 2 \mathrm{v} / \mathrm{v} / \mathrm{v})$ as the developing system.

Standards (S) were cholesterol ester (CE), triglyceride (TG), diglyceride (DG), cholesterol (C), monoglyceride (MG), phospholipid (PL). Phospholipid classes (PL) were separated using chloroform, methanol, hexane, acetic acid, boric acid $(40 / 20 / 30 / 10 / 1.8 \mathrm{v} / \mathrm{v} / \mathrm{v} / \mathrm{v} / \mathrm{w})$ as the developing system. The spots were visualized by iodine vapours.

Standards (S) were phosphatidylethanolamine (PE), phosphatidylserine (PS), phosphatidylinositol (PI), phosphatidylcholine (PC), sphingomyeline (SM), lysophosphatidylcholine (LPC).

B. Elution profile of phospholipid classes separated by preparative high-performance liquid chromatography. The column $(10 \times 250 \mathrm{~mm})$ was packed with silica $(5 \mu \mathrm{m}$ ultrasphere-Si). Two solvent systems described in Material and Methods were used for elution.

Abbreviations are similar to that used in $\mathrm{A}$.

$1-2 \mathrm{mg}$ of phospholipids dissolved in $0.5 \mathrm{ml}$ hexane-2 propanol $(6 / 8 \mathrm{v} / \mathrm{v})$ was pumped onto the column at $2.5 \mathrm{ml} / \mathrm{min}$ and fractions were eluted using the solvent systems described in Material and Methods. The relative mobilities of $\mathrm{PI}$ and PS were inverted in $\mathrm{B}$ as compared to A. 


\section{TABLE 4}

Fatty acid distribution in vitellogenin phospholipids: phosphatidylcholine (PC) and phosphatidylethanolamine (PE), of trout receiving a standard diet.

\begin{tabular}{lcr}
\hline Fatty acid & $\mathrm{PC}$ & \multicolumn{1}{c}{$\mathrm{PE}$} \\
\hline $14: 0$ & $1,0 \pm 0,01$ & $1,4 \pm 0,0$ \\
$16: 0$ & $19,6 \pm 0,4$ & $12,6 \pm 0,0$ \\
$16: 1 \mathrm{n}-9+\mathrm{n}-7$ & $1,7 \pm 0,4$ & $5,9 \pm 0,5$ \\
$18: 0$ & $9,0 \pm 0,1$ & $13,1 \pm 0,1$ \\
$18: 1 \mathrm{n}-3$ & $10,2 \pm 0,5$ & $2,9 \pm 0,2$ \\
$18: 1 \mathrm{n}-7$ & $2,3 \pm 0,05$ & $7,7 \pm 0,2$ \\
$18: 2 \mathrm{n}-6$ & $3,1 \pm 0,05$ & $0,9 \pm 0,1$ \\
$18: 3 \pm 18: 4 \mathrm{n}-3$ & $0,5 \pm 0,01$ & $5,3 \pm 0,4$ \\
$20: 1 \mathrm{n}-9$ & $2,5 \pm 0,05$ & $1,7 \pm 0,1$ \\
$22: 2 \mathrm{n}-6$ & $1,5 \pm 0,1$ & $4,5 \pm 0,0$ \\
$20: 4 \mathrm{n}-6$ & $3,4 \pm 0,01$ & $3,8 \pm 0,1$ \\
$20: 5 \mathrm{n}-3$ & $4,1 \pm 0,05$ & $0,6 \pm 0,0$ \\
$22: 4+22: 5 \mathrm{n}-6$ & $0,6 \pm 0,04$ & $1,1 \pm 0,0$ \\
$22: 5 \mathrm{n}-3$ & $1,7 \pm 0,05$ & $24,1 \pm 0,6$ \\
$22: 6 \mathrm{n}-3$ & $32,7 \pm 0,2$ & $0,5 \pm 0,0$ \\
$24: 1 \mathrm{n}-9$ & $1,5 \pm 0,1$ & 6,2 \\
Other & 4,6 & 14,5 \\
Total $\mathrm{n}-6$ & 8,6 & 29,9 \\
Total $\mathrm{n}-3$ & 39,0 & \\
\hline
\end{tabular}

Data are expressed as mean \pm SEM of two independent determinations. Each of them was performed on pooled samples of serum from four fish.

vitellogenic trout were fed a n-3 deficient diet (Leray et al., 1985) suggest a relationship with the reduction of $n-3$ fatty acids in plasma precursors of oocyte reserves: $\mathrm{LP} \mathrm{d}<1.21 \mathrm{~g} / \mathrm{ml}$ as suggested by recent findings (Black and Skinner, 1987) and vitellogenin. Alterations of the embryo membranes might occur as resulting effects since changes in lipoprotein surface phospholipids influence lipid composition of cell membranes (Owen and Gillett, 1983 ; Owen, Mclntyre and Gillett, 1984). Moreover, it is quite possible that VTG PUFA modulate interactions between the complex and the plasma membrane of the oocyte and affect VTG incorporation since in trout, the yolk cycle presents the features of receptor-mediated endocytosis (Busson-Mabillot, 1984). Therefore phospholipid PUFA directly involved in the metabolic utilization of VTG play a major role in the reproductive process.

Finally even if the distribution of molecular species in VTG remains constant, it is essential to regard the n-3 PUFA content of the phospholipid moiety when considering the nutritional aspects of trout reproduction. Mr A. Linard for skillful technical assistance and Mrs A. Gondouin for typing the manuscrit. 
Résumé. Analyse biochimique de la vitellogénine de truite Arc-en-ciel (Salmo gairdneri). Composition en acides gras des phospholipides.

La vitellogénine a été obtenue à partir de sérum de truites âgées de 3 ans en fin de vitellogenèse.

Deux méthodes d'isolement du complexe ont été comparées: dialyse contre l'eau distillée et ultracentrifugation dans l'intervalle de densité $1,21-1,28 \mathrm{~g} / \mathrm{ml}$.

Les profils obtenus après filtration sur gel et électrophorèse sont identiques quelle que soit la technique de préparation. Ceci démontre que la charge et le poids moléculaire ne sont pas modifiés au cours de la préparation.

Le poids moléculaire apparent de la forme native est de 560000 en filtration sur gel : celui de la forme monomère est estimé à 170000 en électrophorèse sur gel de polyacrylamide-SDS. D'autres protéines sont également présentes; leurs poids moléculaires sont d'environ 100 000-88000 et 78000. Les principaux constituants de la vitellogénine sont les protéines et les lipides qui représentent respectivement $79 \%$ et $19 \%$ du poids sec.

La proportion des glucides est d'environ $0,3 \%$; celle du phosphore protéique $0,7 \%$ et du calcium $0,7 \%$.

Les phospholipides sont les lipides majeurs $(70 \%)$; la principale espèce moléculaire est la phosphatidyicholine dans laquelle l'acide n-3 docosahexaénoïque constitue le tiers des acides grs.

Ces résultats mettent en évidence le degré élevé d'incorporation des acides gras essentiels dans les lipides de structure qui jouent un rôle prépondérant dans le développement de l'embryon.

\section{Références}

ANSARI A. Q., DOLPHIN P. J., LAZIER C. B., MUNDAY K. A., AKHTAR M., 1971. Chemical composition of an estrogen-induced calcium binding glycolipophosphoprotein in Xenopus laevis. Biochem. J., 122, 107-113.

BABIN P. J., 1987. Apolipoprotein and the association of egg yolk proteins with plasma high density lipoproteins after ovulation and follicular atresia in the rainbow trout (Salmo gairdneri). J. biol. Chem., 262, 4290-4296.

BARTLETT C. R., 1959. Phosphorus assay in column chromatography. J. biol. Chem., 234, $466-468$.

BERGINK E. W., KLOOSTERBOER H. J., GRUBER M., AB G., 1973. Estrogen-induced phosphoprotein synthesis in roosters. Kinetics of induction. Biochim. Biophys. Acta, 294, 497-506

BLACK D., SKINNER E. R., 1987. Changes in plasma lipoproteins and tissue lipoprotein lipase and salt-resistant lipase activities during spawning in the rainbow trout (Salmo gairdnerii R.) Comp. Biochem. Physiol., 88B, 261-267.

BUSSON-MABILLOT S., 1984. Endosomes transfer yolk proteins to lysosomes in the vitellogenic oocyte of the trout. Biol. Cell, 51, 53-66.

CAMPBELL C. M., IDLER D. R., 1980. Characterization of an estradiol-induced protein from rainbow trout serum as vitellogenin by the composition and radioimmunological cross reactivity to ovarian yolk fractions. Biol. Reprod., 22, 605-617.

CHEN T. T., 1983. Identification and characterization of estrogen-responses gene products in the liver of rainbow trout. Can. J. Biochem. Cell Biol., 61, 802-810.

DAVIS B. J., 1964. Disc electrophoresis. II. Method and application to human serum proteins. Ann. N. Y. Acad. Sci., 121, 404-427.

DEELEY R. G., MULLINIX K. P., WETEKAM W., KRONENBERG H. M., MEYERS M., ELDRIDGE J. D., GOLDBERGER R. F., 1975. Vitellogenin synthesis in the avian liver. Vitellogenin is the precursor of the egg yolk phosphoproteins. J. biol. Chem., 250, 9060-9066. 
DE VLAMING V. L., WILEY H. S., DELAHUNTY G., WALLACE R. A., 1980. Goldfish (Carassius auratus) vitellogenin: induction, isolation, properties and relationship to yolk proteins. Comp. Biochem. Physiol., 67B, 613-623.

FOLCH J., LEES M., SLOANE STANLEY G. H., 1957. A simple method for the isolation and purification of total lipids from animal tissues. J. biol. Chem., 226, 497-509.

FREMONT L., LEGER C., BOUDON M., 1981. Fatty acid composition of lipids in the trout. II. Fractionation and analysis of plasma lipoproteins. Comp. Biochem. Physiol., 69B, 107-113.

FREMONT L., LEGER C., PETRIDOU B., GOZZELINO M.-T., 1984. Effects of a n-3 polyunsaturated fatty acid-deficient diet on profiles of serum vitellogenin and lipoprotein in vitellogenic trout (Salmo gairdneri). Lipids, 19, 522-528.

GEURTS VAN KESSEL W. S. M., HAXW. M. A., DEMEL R. A., DE GIER J., 1977. High performance liquid chromatography: separation and direct ultraviolet detection of phospholipids. Biochim. Biophys. Acta, 486, 524-530.

GILFILLAN A. M., CHU A. J., SMART D. A., ROONEY S. A., 1983. Single-plate separation of lung phospholipids including disaturated phosphatidylcholine. J. Lipid Res., 24, 1651-1656.

HARA A., HIRAI H., 1978. Comparative studies on immunochemical properties of female-specific serum protein and egg yolk proteins in rainbow trout (Salmo gairdneri). Comp. Biochem. Physiol., 59B, 339-343.

HAVEL R. J., EDER H. A., BRAGDON J. H., 1955. The distribution and chemical composition of ultracentrifugally separated lipoproteins in human serum. J. clin. Invest., 34, 1345-1353.

HORI S. H., KODAMA T., TANAHASHI K., 1979. Induction of vitellogenin synthesis in goldfish by massive doses of androgens. Gen. comp. Endocr., 37, 306-320.

JUANEDA P., ROCQUELIN G., 1985. Rapid and convenient separation of phospholipids and non phosphorus lipids from rat heart using silica cartridges. Lipids, 20, 40-41

KRAAN J. G., MUIR H., 1957. Determination of glucosamine. Biochem. J., 66, 55P.

LAEMMLI U. K., 1970. Cleavage of structural proteins during the assembly of the head of bacteriophage $\mathrm{T}_{4}$. Nature, 227, 680-685.

LERAY C., NONNOTTE G., ROUBAUD P., LEGER C., 1985. Incidence of $\mathrm{n}-3$ essential fatty acid deficiency on trout reproductive process. Reprod. Nutr. Dévelop., 25, 567-581.

LOWRY O. H., ROSEBROUGH N. J., FARR A. L., RANDALLR. J., 1951. Protein measurement with the Folin phenol reagent. J. biol. Chem., 193, 265-275.

NOBLE R. P., 1968. Electrophoretic separation of plasma lipoproteins in agarose gel. J. Lipid Res., 9, 693-700.

NORBERG B., HAUX C., 1985. Induction, isolation and a characterization of the lipid content of plasma vitellogenin from two Salmo species : rainbow trout (Salmo gairdneri) and sea trout (Salmo trutta). Comp. Biochem. Physiol., 81B, 869-876.

OWEN J. S., GILLET M. P. T., 1983; Plasma lipids, lipoproteins and cell membranes. Biochem. Soc. Trans., 11, 336-339.

OWEN J. S., McINTYRE N., GILLETT M. P. T., 1984. Lipoproteins, cell membranes and cellular functions. Trends Biochem. Sci., 9, 238-242.

RIAZI A., FREMONT L., 1988. Serum vitellogenin and yolk proteolipid complex composition in relation to ovarian growth in rainbow trout (Salmo gairdneri). Comp. Biochem. Physiol. (sous presse).

RONDLE C. J. M., MORGAN W. T. J., 1955. The determination of glucosamine and galactosamine. Biochem. J., 27, 586-589.

SEGREST J. P., JACKSON R. L., MORRISETT J. D., GOTTO A. M., 1974. A molecular theory of lipid-protein interactions in the plasma lipoproteins. FEBS Letters, 38, 247-253.

SVENNERHOLM L., 1957. Quantitative estimation of sialic acids. II. A colorimetric resorcinolhydrochloric acid method. Biochim. Biophys. Acta, 24, 604-611.

TATA J. R., 1976. The expression of the vitellogenin gene. Cell, 9, 1-14.

VERRINDER GIBBINS A. M., ROBINSON G. A., 1982. Comparative study of the physiology of vitellogenesis in Japanese quail. Comp. Biochem. Physiol., 72A, 149-155.

VERRINDER GIBBINS A. M., VAN DE VOORT F. R., BRAHAM R., 1981. Comparative study of three different forms of both native and subunit vitellogenin identified in quail plasma. Comp. Biochem. Physiol., 70B, 731-738. 
WALLACE R. A., 1970. Studies on amphibian yolk. IX. Xenopus vitellogenin. Biochim. Biophys. Acta, 215, 176-183.

WALLACE R. A., BERGINK E. W., 1974. Amphibian vitellogenin : Properties, hormonal regulation of hepatic synthesis and ovarian uptake and conversion to yolk proteins. Am. Zool., 14, $1159-1175$

WILEY H. S., OPRESKO L., WALLACE R. A., 1979. New method for the purification of vertebrate vitellogenin. Anal. Biochem. 97, 145-152.

WINZLER R. J., 1955. Determination of serum glycoproteins. In D. GLICK, Methods of biochemical analysis, 2, 279-311. Intersci. Publ. Inc., New York. 